\title{
Manipulating tissue metabolism by amino acids
}

\author{
S. TESSERAUD ${ }^{1 *}$, N. EVERAERT ${ }^{2}$, S. BOUSSAID-OM EZZINE ${ }^{1}$, A. COLLIN ${ }^{1}$, \\ S. MÉTAYER-COUSTARD ${ }^{1}$ and C. BERRI ${ }^{1}$ \\ ${ }^{1}$ INRA, UR83 Recherches Avicoles, 37380 Nouzilly, France; ${ }^{2}$ Department of \\ Biosystems, KU Leuven, 3001 Leuven, Belgium \\ *Corresponding author: sophie.tesseraud@tours.inra.fr
}

Protein metabolism is considered to be regulated by amino acids, with major consequences on tissue development. There is evidence that lysine greatly affects carcass composition and muscle growth. In particular, a drastic effect of dietary provision of lysine has been observed on breast muscle development in chickens. Other essential amino acids, such as threonine and valine, do not have as pronounced an effect as lysine on body composition. Increasing lysine can also improve chicken breast muscle quality by increasing its ultimate $\mathrm{pH}$ and water holding capacity, but the underlying mechanisms are still unknown. Studies conducted over the last ten years indicate that, in addition to being substrates for protein synthesis, amino acids act as modulators of signal transduction pathways that control metabolism and cell functions. For instance, certain amino acids can modulate the activity of the intracellular protein kinases involved in the control of mRNA translation. Interestingly, enhanced responses to amino acids have been reported during the neonatal period, suggesting that early protein nutrition impacts on the development of broiler chicks. Methionine and cysteine have a very significant place among amino acids because they have several additional roles: they are precursors of essential molecules, for example cysteine is used for the synthesis of the antioxidant glutathione, and thus participates in the control of oxidative status, methionine is a source of the methyl groups needed for all biological methylation reactions, including methylation of DNA and histones, etc. These findings together indicate the importance of optimizing amino acid nutrition and providing a rationale for nutritional advice.

Keywords: amino acids; nutrient metabolism; signalling; oxidative stress; methylation process

\section{Introduction}

Amino acids have a major effect on the control of protein metabolism. Provision of the different essential amino acids is a prerequisite for maintenance of optimal rates of

(C) World's Poultry Science Association 2011

World's Poultry Science Journal, Vol. 67, June 2011

Received for publication September 7, 2010

Accepted for publication November 17, 2010 
protein synthesis, and this is an unquestionable major concept in protein nutrition. In other words, amino acids are substrates for protein synthesis and the lack of even a single essential amino acid causes a decrease in protein synthesis. Amino acid availability affects not only protein synthesis rates, but also proteolysis and amino acid oxidation, thus modulating the different pathways involved in protein metabolism. Moreover, studies conducted during the last ten years indicate that amino acids act as regulators of metabolic pathways, with for instance an effect targeted on mRNA translation into proteins.

Amino acids exert their action in various tissues and organs, and in particular they are able to regulate muscle development. The regulation of protein metabolism by amino acids has been studied extensively in skeletal muscle in order to improve muscle growth and meat quality in animal production, and to reduce muscle wasting in some physiological (e.g. early lactation) and physiopathological situations (e.g. ageing, infections, etc). Indeed, due to the differences between the amino acid composition of acute-phase proteins synthesized during catabolic states and that of muscle proteins, a considerable amount of muscle protein has to be degraded to provide the amino acids used in the acute-phase response (Reeds et al., 1994). This review aims to address the important question of how protein nutrition, i.e. provision of amino acids, may contribute to the optimisation of metabolic efficiency and product quality. It also describes the general effects of amino acids with implications for body composition and meat quality. It also highlights the role of amino acids as nutrient signals, which appears to be important for cell functions and metabolic pathways. The last part of this review focuses on sulphur amino acids and their role in controlling oxidative status and the methylation process.

\section{Body composition and muscle quality}

Amino acids are known as anabolic factors, which induce protein gain by stimulating protein synthesis while inhibiting proteolysis. These effects on protein turnover have been clearly demonstrated both in mammals and in avian species (Hocquette et al., 2007; Muramatsu, 1990; Tesseraud et al., 2006 for reviews). Protein-deficient diets cause inhibition of protein synthesis, whereas the effect on proteolysis seems to depend on the severity of the deficiency. Hyperaminoacidemia induced by intravenous infusion of amino acids increases muscle protein synthesis, at least when measurements are performed using the constant infusion of labelled amino acids (Watt et al., 1992; Tesseraud et al., 1993). Amino acids are essential for postprandial stimulation of protein synthesis, as demonstrated in the rat (Yoshizawa et al., 1998) and the chicken (Yaman et al., 2000). Stimulation of protein synthesis by amino acids is associated with an increase in translational efficiency with, in particular, stimulation of the initiation phase which corresponds to the sequential binding of the $40 \mathrm{~S}$ and $60 \mathrm{~S}$ ribosomal subunits on the mRNA molecule. Because re-feeding elicits a rise in plasma concentrations of insulin and amino acids, the role of insulin has also to be considered. Interestingly, some studies have suggested that a minimum level of insulin is required for the stimulation of protein synthesis by re-feeding or amino acids (see Kimball et al., 2002 for a review). Insulin may thus have a permissive effect for the amino acidinduced stimulation of protein synthesis.

Evidence of the action of amino acids in protein turnover has been provided using diets supplemented with or deprived of one or more amino acids. Methionine is for example the first limiting factor in classical diets used for growing chickens because of a high requirement for sulphur amino acids for the synthesis of feathers, whereas poultry diets 
based on corn and soybean meal are deficient in sulphur amino acids without supplementation (Baker, 2006). Decreased growth in chickens fed methionine- and cysteine-free diets is mainly caused by lower rates of whole-body protein synthesis associated with lower RNA efficiency, suggesting translational regulation. Methionine supplementation enhances muscle growth, and the addition of methionine to a methionine-deficient diet, otherwise balanced in terms of other amino acids, increases accretion and synthesis of protein in the Gastrocnemius and Pectoralis major muscles in chickens (Barnes et al., 1995). Similarly, lysine supplementation to a lysine-deficient diet otherwise balanced in terms of other amino acids increases the amounts of protein synthesized and gained in chicken skeletal muscle (Tesseraud et al., 1996a, 2001).

Studies performed using lysine-deficient diets have revealed the possibility of a major effect of dietary amino acid levels on protein degradation: the fractional rates of proteolysis (values expressed as \% per day) measured in the Pectoralis major muscle of growing chickens are always higher in lysine-deprived animals, irrespective of age or genotype (Tesseraud et al., 1996a, 2001). Amino acid deficiency stimulates autophagic (lysosomal degradation) and proteasome-mediated proteolysis (Hamel et al., 2004; Bechet et al., 2005). In chicken muscle, daily variations in dietary lysine content affect the expression of two important genes controlling the ubiquitin-proteasome proteolytic pathway, i.e. E3 ubiquitin ligases Muscle Atrophy F box (MAFbx, also called atrogin-1) and Muscle Ring Finger-1 (MuRF1) (Tesseraud et al., 2009a).

It should be noted that lysine is one amino acid that probably exerts the most specific effects on carcass composition and muscle growth. A particularly drastic effect has been observed on breast muscle development in chickens (Tesseraud et al., 1996a). It is probable that the breast muscle of chickens represents a major reservoir of lysine that can be mobilised in deficiency states. Increased proteolysis in such conditions provides free amino acids that are used for protein synthesis. It is of note that neither threonine nor valine exhibits an effect on body composition as pronounced as that of lysine, as observed in an experiment in which these three amino acids were studied together in similar conditions (Leclercq, 1998). The specific effect of lysine on breast muscle development may be due to the fact that lysine is the most abundant essential amino acid in skeletal muscle protein. Interestingly, a recent study has also revealed that increasing lysine can improve chicken breast muscle quality by increasing its ultimate $\mathrm{pH}$ and water holding capacity (Berri et al., 2008), but the underlying mechanisms have yet to be defined.

Based on findings reported in piglets (Conde-Aguilera et al., 2010), it appears that amino acids modify the chemical composition of tissues with a potential effect on meat quality. In particular, a deficient supply of methionine and/or cysteine affects lipid content and amino acid composition of proteins in muscles.

\section{Nutrient signalling}

Several reviews have reported that amino acids are signal mediators acting on the same intracellular protein kinases as certain hormones (e.g. insulin) (Kimball and Jefferson, 2006a; Dann and Thomas, 2006; Tesseraud et al., 2006; Métayer et al., 2008). Thus, amino acids, in particular the branched-chain amino acid leucine in skeletal muscle, affect the activity of several proteins involved in the control of mRNA translation, such as 4E binding protein (4E-BP1) and $70 \mathrm{kDa}$ ribosomal protein S6 kinase (p70S6K, also called S6K1) (Figure 1). S6K1 and, similarly, 4E-BP1 are phosphorylated in response to insulin via a signal transduction pathway involving phosphatidylinositol-3' kinase (PI3K) and the mammalian target of rapamycin (mTOR) in mammals and avian species (Proud, 
2006; Tesseraud et al., 2007a; Dupont et al., 2009). Amino acid signalling also originates from mTOR, and activates S6K1 and 4E-BP1 (Meijer and Dubbelhuis, 2004; Tesseraud et al., 2006). Despite the increased understanding of the roles of amino acids, many questions still remain and the underlying mechanisms need to be elucidated. One of the key issues relates to the specificity of amino acids acting as 'nutrient signals'. The effects of branched-chain amino acids on the mTOR/S6K1 pathway have been clearly demonstrated (Kimball and Jefferson, 2006b; Yoshizawa, 2004). However, other amino acids may also exert an effect on cell signalling. For example, arginine regulates S6K1 and 4E-BP1 in intestinal cells (Ban et al., 2004), and glutamine can control S6K1 activation and 4E-BP1 phosphorylation induced by arginine or leucine (Nakajo et al., 2005). There are few studies regarding the potential effects of methionine on these intracellular kinases, but they suggest that this sulphur amino acid may have a signal function by inducing S6K1 activation in mammals (Shigemitsu et al., 1999; Stubbs et al., 2002) and avian species (Tesseraud et al., 2003; Métayer-Coustard et al., 2010). In addition, amino acid availability regulates the expression of the E3 ubiquitin ligase atrogin-1 via mTOR in muscle cell lines (Tesseraud et al., 2007b; Herningtyas et al., 2008).

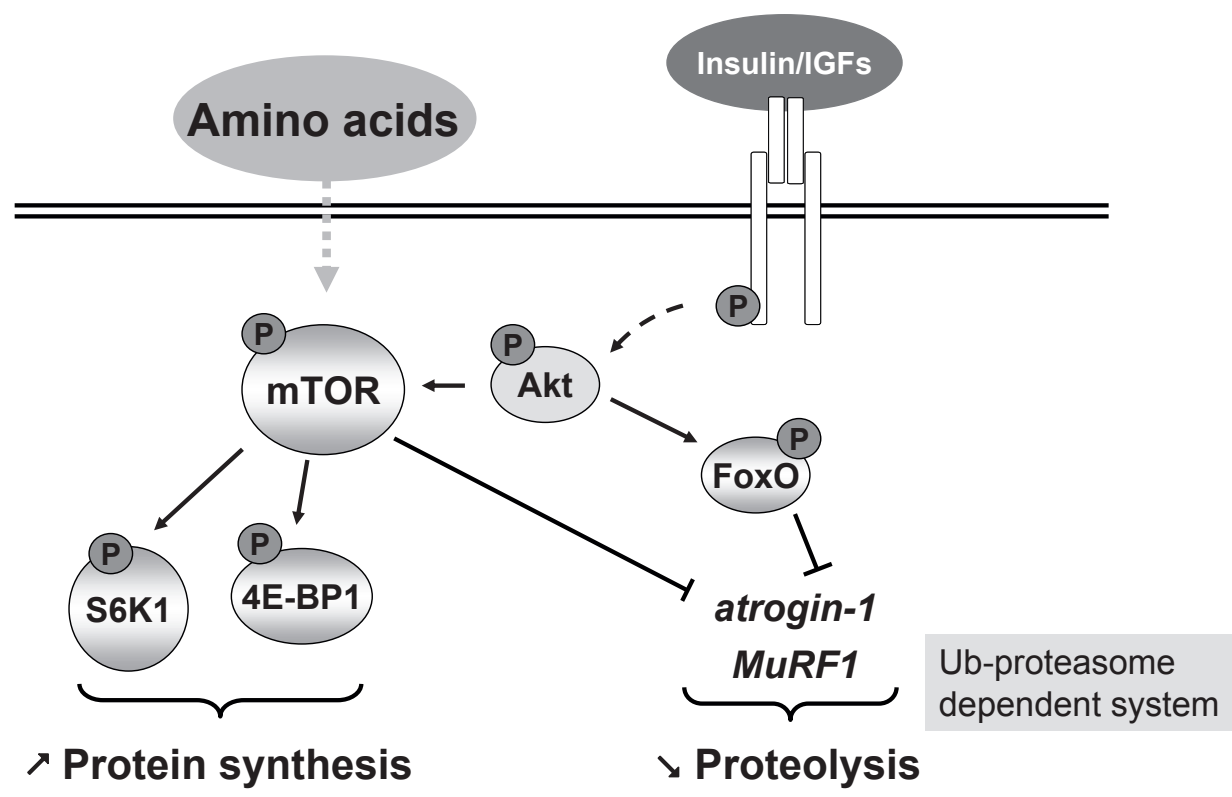

Figure 1 mTOR signalling and control of protein synthesis and proteolysis. Akt or PKB, protein kinase B; atrogin-1 or MAFbx, muscle atrophy $F$ box; 4E-BP1, eukaryotic initiation factor $4 \mathrm{E}$ binding protein; FoxO, forkhead box-O transcription factor; mTOR, mammalian target of rapamycin; MuRF1, Muscle Ring Finger-1; S6K1, 70 kDa ribosomal protein S6 kinase.

Interestingly, the activation by feeding and by amino acids of components related to translation initiation is developmentally regulated, with enhanced responses during the neonatal period, as reported by several studies in piglets (Suryawan et al., 2001, 2007). Decreased stimulation with age parallels the developmental decline in protein synthesis in skeletal muscle, which is due to lower efficiency of the translation process and depressed synthesis capacity (Davis et al., 2008). Similar age-related changes might exist in avian species since developmental declines in the capacity for protein synthesis (Tesseraud et 
al., 1996b) and in the abundance of kinases involved in intracellular signalling (Vaudin et al., 2006) have been reported in chick muscle. Considering the drastic effects of amino acids on proteins related to translation initiation in the neonatal period (Escobar et al., 2006, 2007), consumption of an amino acid-enriched diet could be particularly valuable to improve protein synthesis and growth in this critical period. A recent study performed in neonatal chicks showed that the consumption of a high protein diet clearly activated S6K1 and augmented its activity in the breast muscle (Everaert et al., 2010). These findings indicated that the activation of S6K1 is sensitive to dietary amino acid provision during early feeding, which could potentially enhance the translation of mRNA in skeletal muscle of neonatal chicks.

One unsolved issue concerns the multiple effects of amino acids on cell functioning. The role of amino acids as nutrient signals appears to be important for cell functions and metabolic pathways, other than those directly concerned with protein turnover. For example, amino acids may be strong modulators of glucose metabolism and insulin sensitivity. In vitro and in vivo findings indicate an important role of amino acids in glucose homeostasis through inhibition of insulin action on muscle glucose transport and hepatic glucose production. This negative effect of amino acids on insulin action appears to be associated with mTOR/S6K1-dependent inhibitory phosphorylation of insulin receptor substrate-1 (IRS-1) on serine and/or threonine residues and impaired activation of PI3K, a key effector of the metabolic actions of insulin (Tremblay et al., 2007; Um et al., 2006). Depletion of S6K1 was recently shown to enhance basal glucose utilization in mammalian muscle cells and to protect against the development of impaired insulin action in response to excessive leucine (Deshmukh et al., 2009). More information is therefore needed on the potential effects of amino acid supplementation before use for nutritional purposes.

\section{Sulphur amino acids, control of oxidative status and methylation process}

As precursors of various molecules, amino acids have other major functions. For instance, the antioxidants glutathione and cysteine, originating from methionine metabolism, can function as direct scavengers of reactive oxygen species (ROS), formed at the mitochondrial level and producing deleterious effects such as lipid and protein oxidation or DNA strand-break damage. Glutathione, which is a tripeptide (Lglutamyl-L-cysteinyl-glycine), is the most important intracellular antioxidant in the body (Obled et al., 2004; Reid and Jahoor, 2001). Acute infection increases its synthesis in various tissues (liver, spleen, lung and muscles), accounting for at least $40 \%$ of the enhanced cysteine utilisation during infection in the rat (Malmezat et al., 2000). Methionine metabolism was affected in normal volunteers subjected to a mild inflammatory challenge (i.e. vaccination; Mercier et al., 2006), in agreement with results obtained in acute diseases. Preferential methionine metabolism toward cysteine synthesis has thus been observed, indicating increased requirement for sulphur amino acids in these situations. Interestingly, using everted sac techniques with chicken intestine, it was demonstrated that the methionine hydroxy-analog, DL-2-Hydroxy-(4Methylthio) butanoic acid, is more efficiently converted to cysteine and taurine than Lmethionine through the trans-sulphuration pathway, suggesting that this hydroxy-analog of methionine might have a different role in detoxification processes than methionine itself (Martin-Venegas et al., 2006).

Sulphur amino acids are involved in the methionine sulphoxide reductase anti-oxidant system (Moskovitz et al., 1995; Levine et al., 1996). Methionine residues in proteins are 
particularly susceptible to oxidation by ROS and are converted to methionine sulphoxide, which can be reduced back to methionine by methionine sulphoxide reductases. Each cycle of methionine oxidation and reduction will destroy one equivalent of ROS, which might represent a major natural scavenging system for ROS. The methionine sulphoxide reductase system is particularly involved in the repair of oxidized proteins, thereby preventing cellular accumulation of damaged proteins (Stadtman et al., 2005). Nevertheless, the effects of different sulphur compounds in critical physiopathological conditions is not yet fully understood, especially with regard to host defence against oxidative stress and protection against lipid and protein oxidation. These findings that impact on tissue metabolism have potential implications for animal health, tissue development and product (meat) quality.

Methionine is a source of methyl groups that are used to methylate DNA, a process that influences chromatin structure and gene expression. The mechanisms involved have been detailed in a recent review and therefore will not be presented here (Tesseraud et al., $2009 b$ ). From a nutritional point of view, one interesting application concerns perinatal nutrition since aberrant methyl metabolism in early life is linked with disorders. This means that manipulating the sulphur amino acid content of the early diet may induce chronic changes in cell functions that have implications for long-term health. For instance, it has been shown in mammals that changes within physiological ranges in the supply of methionine and specific B vitamins such as B12 during the periconception period can lead to widespread epigenetic changes in DNA methylation in offspring, and can modify adult health-related phenotypes (Sinclair et al., 2007). To our knowledge, such epigenetic regulation by nutrients has not yet been investigated in avian species, although there is evidence of epigenetic changes in chicks after heat-conditioning (Kisliouk et al., 2010).

\section{Amino acids, numerous roles and functions ...}

\section{Mechanisms involved? Consequences on growth and meat quality?}

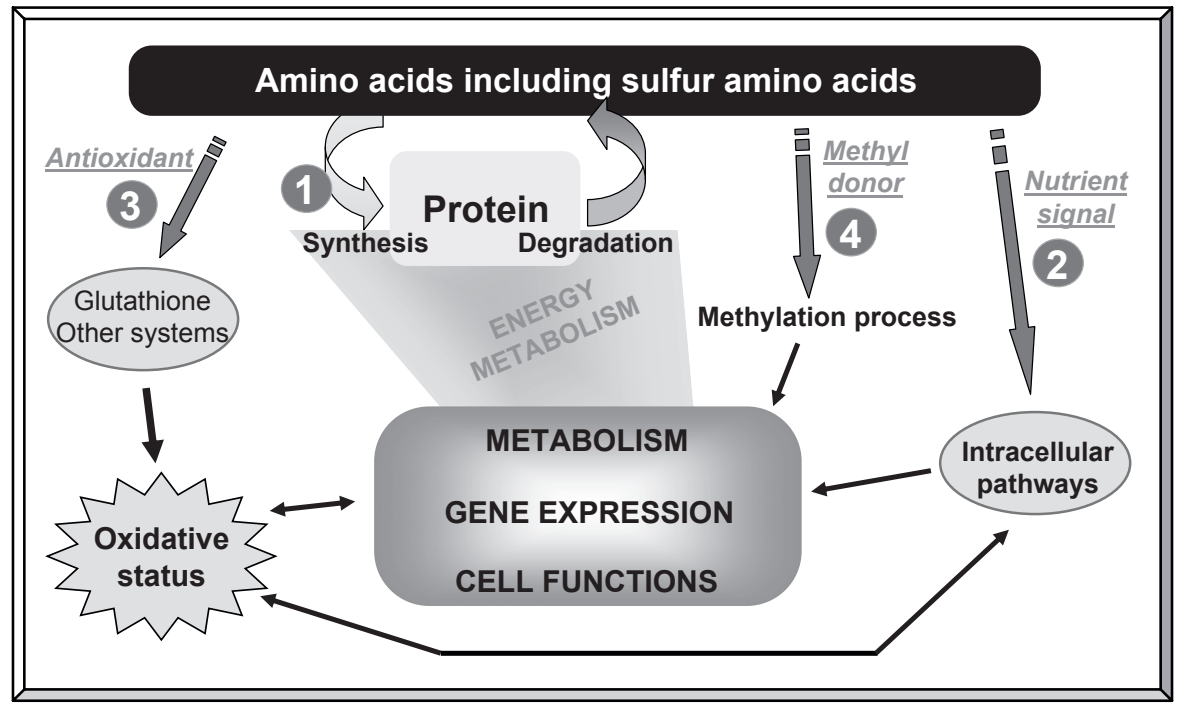

Figure 2 Regulation of metabolism, numerous roles played by amino acids: 1) precursors of protein synthesis, 2) nutrient signal, 3) antioxidant function and 4) methyl group donor. The figure represents a summary of findings discussed in the present review. 


\section{Conclusions}

Amino acids are recognised to be essential in controlling metabolism (Figure 2). Despite the increased understanding of the role of amino acids, many questions still remain unanswered. Identifying the mechanisms by which amino acids regulate metabolism, signalling, gene expression and cell functioning is thus essential to improve the control of nutrient utilisation and to optimise dietary amino acid provision for animal production purposes.

\section{Acknowledgements}

The authors thank I. Seiliez (INRA, St Pée-sur-Nivelle, France) for valuable discussions, and D. Raine (Surrey, UK) for editing the English language.

\section{References}

BAKER, D.H. (2006) Comparative species utilization and toxicity of sulphur amino acids. The Journal of Nutrition 136: 1670S-1675S.

BAN, H., SHIGEMITSU, K., YAMATSUJI, T., HAISA, M., NAKAJO, T., TAKAOKA, M., NOBUHISA, T., GUNDUZ, M., TANAKA, N. and NAOMOTO, Y. (2004) Arginine and Leucine regulate p70 S6 kinase and 4E-BP1 in intestinal epithelial cells. International Journal of Molecular Medicine 13: 537-543.

BARNES, D.M., CALVERT, C.C. and KLASING, K.C. (1995) Methionine deficiency decreases protein accretion and synthesis but not tRNA acylation in muscles of chicks. The Journal of Nutrition 125: 2623-30.

BECHET, D., TASSA, A., COMBARET, L., TAILLANDIER, D. and ATTAIX, D. (2005) Regulation of skeletal muscle proteolysis by amino acids. Journal of Renal Nutrition 15: 18-22.

BERRI, C., BESNARD, J. and RELANDEAU, C. (2008) Increasing dietary lysine increases final pH and decreases drip loss of broiler breast meat. Poultry Science 87: 480-4.

CONDE-AGUILERA, J.A., BAREA, R., LE FLOC'H, N., LEFAUCHEUR, L. and VAN MILGEN, J. (2010) A sulphur amino acid deficiency changes the amino acid composition of body protein in piglets. Animal 4: 1349-1358, doi:10.1017/S1751731110000340.

DANN, S.G. and THOMAS, G. (2006) The amino acid sensitive TOR pathway from yeast to mammals. FEBS Letters 580: 2821-2829.

DAVIS, T.A., SURYAWAN, A., ORELLANA, R.A., NGUYEN, H.V. and FIOROTTO, M.L. (2008) Postnatal ontogeny of skeletal muscle protein synthesis in pigs. Journal of Animal Science 86: E13-8.

DESHMUKH, A., SALEHZADEH, F., METAYER-COUSTARD, S., FAHLMAN, R., NAIR, K.S. and AL-KHALILI, L. (2009) Post-transcriptional gene silencing of ribosomal protein S6 kinase 1 restores insulin action in leucine-treated skeletal muscle. Cellular and Molecular Life Sciences 66: 1457-66.

DUPONT, J., TESSERAUD, S. and SIMON, J. (2009) Insulin signalling in chicken liver and muscle. General and Comparative Endocrinology 163: 52-7.

ESCOBAR, J., FRANK, J.W., SURYAWAN, A., NGUYEN, H.V. and DAVIS, T.A. (2007) Amino acid availability and age affect the leucine stimulation of protein synthesis and eIF4F formation in muscle. The American Journal of Physiology 293: E1615-21.

ESCOBAR, J., FRANK, J.W., SURYAWAN, A., NGUYEN, H.V., KIMBALL, S.R., JEFFERSON, L.S. and DAVIS, T.A. (2006) Regulation of cardiac and skeletal muscle protein synthesis by individual branchedchain amino acids in neonatal pigs. The American Journal of Physiology 290: E612-E621.

EVERAERT, N., SWENNEN, Q., COUSTARD, S.M., WILlEMSEN, H., CAREGHI, C., BUYSE, J., BRUGGEMAN, V., DECUYPERE, E. and TESSERAUD, S. (2010) The effect of the protein level in a pre-starter diet on the post-hatch performance and activation of ribosomal protein S6 kinase in muscle of neonatal broilers. British Journal of Nutrition 103: 206-11.

HAMEL, F.G., FAWCETT, J., BENNETT, R.G. and DUCKWORTH, W.C. (2004) Control of proteolysis: hormones, nutrients, and the changing role of the proteasome. Current Opinion in Clinical Nutrition and Metabolic Care 7: 255-58.

HERNINGTYAS, E.H., OKIMURA, Y., HANDAYANINGSIH, A.E., YAMAMOTO, D., MAKI, T., IIDA, K., TAKAHASHI, Y., KAJI, H. and CHIHARA, K. (2008) Branched-chain amino acids and arginine suppress MaFbx/atrogin-1 mRNA expression via mTOR pathway in $\mathrm{C} 2 \mathrm{C} 12$ cell line. Biochimica et Biophysica Acta 1780: 1115-20. 
HOCQUETTE, J.F., TESSERAUD, S., CASSAR-MALEK, I., CHILLIARD, Y. and ORTIGUESMARTY, I. (2007) Responses to nutrients in farm animals: implications for production and quality. Animal 1: 1297-1313.

KIMBALL, S.R. and JEFFERSON, L.S. (2006a) New functions for amino acids: effects on gene transcription and translation. The American Journal of Clinical Nutrition 83: 500S-507S.

KIMBALL, S.R. and JEFFERSON, L.S. (2006b) Signaling pathways and molecular mechanisms through which branched-chain amino acids mediate translational control of protein synthesis. The Journal of Nutrition 136: 227S-231S.

KIMBALL, S.R., FARRELL, P.A. and JEFFERSON, L.S. (2002) Invited Review: Role of insulin in translational control of protein synthesis in skeletal muscle by amino acids or exercise. Journal of Applied Physiology 93: 1168-1180.

KISLIOUK, T., ZIV, M. and MEIRI, N. (2010) Epigenetic control of translation regulation: alterations in histone $\mathrm{H} 3$ lysine 9 post-translation modifications are correlated with the expression of the translation initiation factor 2B (Eif2b5) during thermal control establishment. Developmental Neurobiology 70: 100-13.

LECLERCQ, B. (1998) Specific effects of lysine on broiler production: comparison with threonine and valine. Poultry Science 77: 118-123.

LEVINE, R.L., MOSONI, L., BERLETT, B.S. and STADTMAN, E.R. (1996) Methionine residues as endogenous antioxidants in proteins. Proceedings of the National Academy of Sciences of the United States of America 93: 15036-15040.

MAlMEZAT, T., BREUIlle, D., CAPITAN, P., MIRAND, P.P. and OBLED, C. (2000) Glutathione turnover is increased during the acute phase of sepsis in rats. The Journal of Nutrition 130: 1239-46.

MARTIN-VENEGAS, R., GERAERT, P.A. and FERRER, R. (2006) Conversion of the Methionine Hydroxy Analogue, DL-2-Hydroxy-(4-Methylthio) butanoic Acid, to Sulphur-Containing Amino Acids in the Chicken Small Intestine. Poultry Science 85: 1932-8.

MEIJER, A.J. and DUBBELHUIS, P. (2004) Amino acid signalling and the integration of metabolism. Biochemical and Biophysical Research Communications 313: 397-403.

MERCIER, S., BREUILLE, D., BUFFIERE, C., GIMONET, J., PAPET, I., MIRAND, P.P. and OBLED, C. (2006) Methionine kinetics are altered in the elderly both in the basal state and after vaccination. American Journal of Clinical Nutrition 83: 291-98.

MÉTAYER-COUSTARD, S., MAMERI, H., SEILIEZ, I., CROCHET, S., CRÉPIEUX, P., MERCIER, Y., GERAERT, P.A. and TESSERAUD, S. (2010) Methionine deprivation regulates the S6K1 pathway and protein synthesis in avian QM7 myoblasts without activating the GCN2/eIF2 cascade. The Journal of Nutrition 140: 1539-1545.

MÉTAYER, S., SEILIEZ, I., COLlin, A., DUCHÊNE, S., MERCIER, Y., GERAERT, P.A. and TESSERAUD S. (2008) Mechanisms through which sulphur amino acids control protein metabolism and oxidative status. The Journal of Nutritional Biochemistry 19(4): 207-15.

MOSKOVITZ, J., RAHMAN, M.A., STRASSMAN, J., YANCEY, S.O., KUSHNER, S.R., BROT, N. and WEISSBACH, H. (1995) Escherichia coli peptide methionine sulphoxide reductase gene: regulation of expression and role in protecting against oxidative damage. Journal of Bacteriology 177: 502-507.

MURAMATSU, T. (1990) Nutrition and whole-body protein turnover in the chicken in relation to mammalian species. Nutrition Research Reviews 3: 211-28.

NAKAJO, T., YAMATSUJI, T., BAN, H., SHIGEMITSU, K., HAISA, M., MOTOKI, T., NOMA, K., NOBUHISA, T., MATSUOKA, J., GUNDUZ, M., YONEZAWA, K., TANAKA, N. and NAOMOTO, Y. (2005) Glutamine is a key regulator for amino acid-controlled cell growth through the mTOR signalling pathway in rat intestinal epithelial cells. Biochemical and Biophysical Research Communications 326: 174180 .

OBLED, C., PAPET, I. and BREUILLE, D. (2004) Sulphur-containing amino acids and glutathione in diseases., in: CYNOBER, L.A. (Ed.) Metabolic and therapeutic aspects of amino acids in clinical nutrition, 2nd ed., pp 667-687, Boca Raton (CRC Press LLC).

PROUD, C.G. (2006) Regulation of protein synthesis by insulin. Biochemical Society Transactions 34: 213-6.

REEDS, P.J., FJELD, C.R. and JAHOOR, F. (1994) Do the differences between the amino acid compositions of acute-phase and muscle proteins have a bearing on nitrogen loss in traumatic states? The Journal of Nutrition 124: 906-10.

REID, M. and JAHOOR, F. (2001) Glutathione in disease. Current Opinion in Clinical Nutrition and Metabolic Care 4: 65-71.

SHIGEMITSU, K., TSUJISHITA, Y., MIYAKE, H., HIDAYAT, S., TANAKA, N., HARA, K. and YONEZAWA, K. (1999) Structural requirement of leucine for activation of p70 S6 kinase. FEBS Letters 447: 303-306. 
SINCLAIR, K.D., ALLEGRUCCI, C., SINGH, R., GARDNER, D.S., SEBASTIAN, S., BISPHAM, J., THURSTON, A., HUNTLEY, J.F., REES, W.D., MALONEY, C.A., LEA, R.G., CRAIGON, J., MCEVOY, T.G. and YOUNG, L.E. (2007) DNA methylation, insulin resistance, and blood pressure in offspring determined by maternal periconceptional B vitamin and methionine status. Proceedings of the National Academy of Sciences of the United States of America 104: 19351-19356.

STADTMAN, E.R., VAN REMMEN, H., RICHARDSON, A., WEHR, N.B. and LEVINE, R.L. (2005) Methionine oxidation and aging. Biochimica et Biophysica Acta 1703: 135-140.

STUBBS, A.K., WHEELHOUSE, N.M., LOMAX, M.A. and HAZLERIGG, D.G. (2002) Nutrient-hormone interaction in the ovine liver: methionine supply selectively modulates growth hormone-induced IGF-I gene expression. Journal of Endocrinology 174: 335-341.

SURYAWAN, A., NGUYEN, H.V., BUSH, J.A. and DAVIS, T.A. (2001) Developmental changes in the feeding-induced activation of the insulin-signaling pathway in neonatal pigs. The American Journal of Physiology 281: E908-E915.

SURYAWAN, A., ORELLANA, R.A., NGUYEN, H.V., JEYAPALAN, A.S., FLEMING, J.R. and DAVIS, T.A. (2007) Activation by insulin and amino acids of signalling components leading to translation initiation in skeletal muscle of neonatal pigs is developmentally regulated. The American Journal of Physiology 293: E1597-605.

TESSERAUD, S., ABBAS, M., DUCHENE, S., BIGOT, K., VAUDIN, P. and DUPONT, J. (2006) Mechanisms involved in the nutritional regulation of mRNA translation: features of avian model. Nutrition Research Reviews 19: 104-116.

TESSERAUD, S., BIGOT, K. and TAOUIS, M. (2003) Amino acid availability regulates S6K1 and protein synthesis in avian insulin-insensitive QM7 myoblasts. FEBS Letters 540: 176-180.

TeSSERAUd, S., BOUVAREL, I., COLlin, A., AUDOUIN, E., CROChet, S., SEILIEZ, I. and LETERRIER, C. (2009a) Daily variations in dietary lysine content alter the expression of genes related to proteolysis in chicken pectoralis major muscle. The Journal of Nutrition 139: 38-43.

TESSERAUD, S., GRIZARD, J., DEBRAS, E., PAPET, I., BONNET, Y., BAYLE, G. and CHAMPREDON, C. (1993) Leucine metabolism in lactating and dry goats: effect of insulin and substrate availability, American Journal of Physiology 265: E402-13.

TESSERAUd, S., MÉTAYER COUSTARD, S., COLLIN, A. and SEILIEZ, I. (2009b) Role of sulphur amino acids in controlling nutrient metabolism and cell functions: implications for nutrition. British Journal of Nutrition 101: 1132-9.

TESSERAUD, S., MÉTAYER, S., DUCHÊNE, S., BIGOT, K., GRIZARD, J. and DUPONT, J. (2007a) Regulation of protein metabolism by insulin: value of different approaches and animal models. Domestic animal Endocrinology 33: 123-42.

TESSERAUD, S., MÉTAYER-COUSTARD, S., BOUSSAID, S., CROCHET, S., AUDOUIN, E., DEROUET, M. and SEILIEZ, I. (2007b) Insulin and amino acid availability regulate atrogin-1 in avian QT6 cells. Biochemical and Biophysical Research Communications 357: 181-6.

TESSERAUD, S., PERESSON, R. and CHAGNEAU, A.M. (1996b) Age-related changes of protein turnover in specific tissues of the chick. Poultry Science 75: 627-31.

TeSseraUd, S., PERESSON, R., LOPES, J. and CHAGNEAU, A.M. (1996a) Dietary lysine deficiency greatly affects muscle and liver protein turnover in growing chickens. British Journal of Nutrition 75: 853-65.

TESSERAUD, S., TEMIM, S., LE BIHAN-DUVAL, E. and CHAGNEAU, A.M. (2001) Increased responsiveness to dietary lysine deficiency of pectoralis major muscle protein turnover in broilers selected on breast development. Journal of Animal Science 79: 927-33.

TREMblay, F., LAVIGNE, C., JACQUES, H. and MARETTE, A. (2007) Role of dietary proteins and amino acids in the pathogenesis of insulin resistance. Annual Review of Nutrition 27: 293-310.

UM, S.H., D'ALESSIO, D. and THOMAS, G. (2006) Nutrient overload, insulin resistance, and ribosomal protein S6 kinase 1, S6K1. Cell Metabolism 3: 393-402.

VAUDIN, P., DUPONT, J., DUCHÊNE, S., AUDOUIN, E., CROCHET, S., BERRI, C. and TESSERAUD, S. (2006) Phosphatase PTEN in chicken muscle is regulated during ontogenesis. Domestic Animal Endocrinology 31: 123-140.

WATT, P.W., CORBETT, M.E. and RENNIE, M.J. (1992) Stimulation of protein synthesis in pig skeletal muscle by infusion of amino acids during constant insulin availability. American Journal of Physiology 262 : E453-60.

YAMAN, M.A., KITA, K. and OKUMURA, J. (2000) Various macronutriments intakes additively stimulate protein synthesis in liver and muscle of food-deprived chicks. The Journal of Nutrition 130: 70-76.

YOSHIZAWA, F. (2004) Regulation of protein synthesis by branched-chain amino acids in vivo. Biochemical and Biophysical Research Communications 313: 417-422.

YOSHIZAWA, F., KIMBALL, S.R., VARY, T.C. and JEFFERSON, L.S. (1998) Effect of dietary protein on translation initiation in rat skeletal muscle and liver. American Journal of Physiology 275: E814-20. 
252 World's Poultry Science Journal, Vol. 67, June 2011 